\title{
Ethnic Community Variation and Change in Over-Family Size in Bangladesh: 1971-2011
}

\author{
A. H. M. Mahbubur Rahman* Ph. D \\ Associate Professor, Department of Social Work, Tejgaon College, Dhaka, Bangladesh \\ *Corresponding Author: A. H. M. Mahbubur Rahman, Associate Professor, Department of Social \\ Work, Tejgaon College, Dhaka, Bangladesh
}

\begin{abstract}
Ethnic community variations in over-family size affect not only ethnic family and community life but also influence national development and social welfare functions in Bangladesh. Based on optimum population theory the government of Bangladesh has adopted two-child (either male or female) family size policy. To achieve this goal mentioned in the policy family planning and contraceptive services have been providing to the eligible couples since 1971. But data collected over the 1974-2011 census periods reveal that although average over-family size is gradually shifting into smaller one, average family size of majority ethnic Muslim community over the census periods is higher than that in the other religious ethnic groups (e.g., Hindu, Christian Budhist). Using census 1974-2011 data this seminal paper describes ethnic community variations and changes in over-family size in Bangladesh. Based on the description new social policyprograms and social workers' role across the individual, group, and community level are discussed to achieve optimum family size for meeting human needs and healthy ethnic family adaptation in Bangladesh.
\end{abstract}

Keywords: Ethnic Community, Over-Family Size, Social Policy-Programs, Social Work Implication, Bangladesh

\section{INTRODUCTION}

Over-family size is a serious social issue across the developing and less-developed societies, including Bangladesh (United Nations, 1963, 1993, 2000, 2001). Family social scientists, demographers and policy-makers suggest an optimum family size to meet basic human needs and to maintain healthy family life for better ethnic family adaptation to the changing environment (Gill, 1995; United Nations, 1993). Periodical research and census report indicate that over-family size prevails across the ethnic groups in Bangladesh (Bangladesh Bureau of Statistics, BBS, 1974, 2001; Mitra \& Kamal, 1985). Reducing over-family size the government of Bangladesh in the 1970s formulated small family size policy, especially two-child policy for per couple or family (Mitra \& Kamal, 1985). Since then the government of Bangladesh in cooperation with voluntary, nongovernmental and international organizations has been encouraging eligible couples to achieve small family size norms, providing family planning and birth control facilities, health care for mothers and their infants (Uddin \& Ferdous, 2009). In the 1980s the concern authority further revised the family size policy and reformulated one child policy, like China. In addition to early social services, the government had emphasized on the couples' socio-economic development and cultural change in the sense that would reduce over-family size across the ethnic groups.

But relevant research studies (Uddin, 2010) and population census reports (Bangladesh Bureau of Statistics, 2013) have shown that although average family size has shifted into smaller ones (from 5.7 in 2001 to 4.5 in 2010), overall family size is still too much higher than the family size expected at national and ethnic community level. This over-family size in association with limited resources affects not only fulfillment of family basic human needs, proper child development and maintenance of healthy family life across the ethnic communities, but it also accelerates social problems, including over-population, density rate, maternal and child mortality rate, poverty, crime, illiteracy, unemployment, health problem, violence, child abuse, human trafficking, and degrading natural environment) at national level (Barkat \& Howlader, 1996; Bangladesh Bureau of Statistics, 2000).

Despite ethnic community variations and changes in over-family size prevailed across the census periods in Bangladesh, there is little research on the issue. Purpose of the study is to describe ethnic 
community variations in over-family size in Bangladesh. Second aim is to describe its proper application by social workers to change over-family size into smaller ones across the ethnic community groups in Bangladesh.

\section{DATA AND METHOD}

Bangladesh is a small but poverty-stricken country located in South Asian region with 147,570 square kilometers. It is almost entirely surrounded by India, except for a short southeastern frontier with Myanmar and a south deltaic coastline on the Bay of Bengal. It stretches between $20^{\circ} 41^{\prime}$ east longitude (Mitra et al., 1994; Mitra and Kamal, 1985). The country has the largest delta lands and a flat alluvial plain crisscrossed by the major rivers: Padma, Meghna, Jamuna, and their many tributaries in the world that are important in the people' economic, socio-cultural, and religious life. The country has also a sub-tropical climate with three prominent seasons: monsoon, winter, and summer and three less prominent seasons. Mean annual temperatures vary between $57^{\circ} \mathrm{F}$ and $80^{\circ} \mathrm{F}$, and annual rainfall from 50 inches in the west to 100 inches in the south-east and 200 inches in the Lilly regions of the north (Mitra and Kamal, 1985). Administratively, the country is classified into six divisions, 64 districts, and 507 thanas/upazila. Although Bangladesh is predominantly a rural country, she has 6 city corporations: Dhaka, Rajshahi, Khulna, Chittagong, Shilhet, Barishal, and 223 Municipalities and 59990 mouzas (Bangladesh Bureau of Statistics, 2000). Socio-culturally, Muslims are dominant ethnic group, constituting $85 \%$ of the population of Bangladesh. The rest of them (15\%) are the Hindus, Christians, and Buddhists. A small fraction of the population consists of several ethnic/tribal groups who are distinct in terms of language, race, religion, and customs. Although the national language of Bangladesh is Bengali, they all use dual language in conversation with the major religious/cultural groups (e.g., Muslim, Hindu).

The data on description of ethnic community variations and changes in over-family size used in this study were secondary in nature and were obtained from the reports of UNICEF (1996, 1997, 2001), United Nations (2001) and Statistical Yearbook of Bangladesh (1982, 1991, 1997, 2001, 2002). The data that were derived from the sources were more reliable and valid in the logics that were collected through systematic methodology by the world recognized experts. The data on average family size over the census years presented in the findings section were analyzed across the national, divisional, district, and ethnic community settings. In addition, due to variations and gradual changes in the demographic and socio-economic status in national, divisional, and rural-urban or inter-religious communities, average family size was different and likely occurred changes among them. The methods of data analysis in this paper were historical and comparative one through which we analyzed and compared variations and changes in average family size from 1971 to 2011 in respect of rural-urban and inter-religious communities in Bangladesh. These methods and its analysis were fruitful to observe development and trends in average family size prevalence and change over the years across the ethnic community groups in Bangladesh.

\section{ETHNIC COMMUNITY VARIATION IN OVER-FAMILY SIZE: 1971-2011}

Family size is the foundation of population size in a given society. It varies across the social classes, religious/ethnic groups and regions due to variations in biological, social, demographic, cultural, political, economic and psychological status achieved in the given society. It also changes over the time periods due to changes in those characteristics in the given society. The following section analyzes data derived from inter-census reports on ethnic community variations and changes in average family size in Bangladesh from 1971 to 2001.

\subsection{Districts Variations}

There is a paucity of data to describe ethnic community variations in average family size in the former 21 districts of Bangladesh. Inter-census data derived from the census year 1974 to 1981 to 1991 showed that average family size of those districts was 5.36 in 1974, 5.87 in 1981 and 5.60 in 1991. In this respect average family size increased in 1981, but it declined in 1991 to some extent. In 19741981 census period, when average family in some former districts size was 6 and above, in another some districts average family size was 4 and above, in 1991 average family size of all districts were 5 and above. However, average family size was different from 2 to 3 persons for per couple in the districts in Bangladesh. 


\subsection{Divisional Variations}

Ethnic community variations in average family size are reflected in divisions of Bangladesh. In so doing we used two censuses data, 1991 and 2011. During the census period of 1991 and 2011 average family size at national level was 5.6 and 4.8 respectively. In this period division-wise average family size of the ethnic community was remarkable. In 1991 census year average family size of Sylhet division of the Muslim community was the higher (6.1) than Chittagong (5.9), Khulna (5.6), Barisal (5.6), Rajshahi (5.4) and Dhaka (5.4) than the Hindu (5.9 for Sylhet, 5.8 for Chittagong, 5.7 for Khulna, 5.5 for Barisal, 5.4 for Rajshahi \& 5.3 for Dhaka), Christian (5.7 for Sylhet, 5.5 for Chittagong, 5.4 for Khulna, 5.3 for Barisal, 5.4 for Rajshahi \& 5.2 for Dhaka)and Budhist (5.8 for Sylhet, 5.7 for Chittagong, 5.6 for Khulna, 5.3 for Barisal, 5.2 for Rajshahi \& 5.1 for Dhaka) community. But in 2001 census it was 5.7 in Sylhet compared to Chittagong (5.4), Barisal (4.9), Dhaka (4.7), Khulna (4.6) and Rajshahi (4.5). In both the censuses period average family size of the Muslim compared to other communities was the highest in the Sylhet Division (6.1 and 5.7), but it was the lowest in the Rajshahi Division (5.4 and 4.5). However, average family size in the intercensus period was 1 to 3 person variations in family size across the ethnic communities in Bangladesh.

\subsection{Rural, Urban and Municipal Variations}

Variations in average family size among the major religious groups are reflected in rural, urban and municipal background during the census period of 1991. In this respect average family size of Muslim, Hindu, Budhist, Christian and Tribals was 5.49, 5.44, 5.32, 4.98, and 4.99 respectively. During this period average family size of the Muslims was higher than the Hindu, the Buddhist, the tribal and the Christian. It was interesting to note that average family size by Muslim with rural (5.49), urban (5.47) and municipal (5.51) background was also higher than the Hindu (5.42 for rural, 5.53 for urban and 5.50 for municipal), the Buddhist (5.34 for rural, 5.21 for urban and 5.29 for municipal), the Christian (4.38 for rural, 5.03 for urban and 4.36 for municipal) and the Tribal (4.98 for rural, 5.14 for urban and 5.10 for municipal) respectively. In this respect, Muslim family size by rural and municipal background is high (5.49), but Hindu family size by urban background is high (5.53).

\section{ETHNiC COMMUNity CHANGES IN OVER-FAMILY SizE: 1971-2011}

We have already analyzed variations in average family size, focusing on division, former districts and religious communities in Bangladesh. Like variations average family size also changes across the regions and ethnic community groups. Now we will turn our attention to changes in average family size in divisional, rural, urban and municipal context.

\subsection{Changes in Average Family Size in Division}

Unlike ethnic variations, ethnic family size changes by 4 major divisions, including Dhaka, Chittagong, Khulna and Rajshahi in Bangladesh. The data showed that average family size was gradually shifting into smaller one at both divisional and national level over the census years, 19742011. The change rate between 1974 and 1981 census years at national level was slower (11\%) than that in the next two census years (79\%), 1991 and 2011. In division-wise the rate of family size change of the minority ethnic groups (e.g., Hindu, Christian, Budhist) in the Khulna division (37\%) was higher than the Muslim community in the Chittagong (32\%) and Dhaka division (30\%) between 1974 and 1981 census years. But this rate of the Rajshahi division (92\%) in next two census years, 1991 and 2001 of the former, compared to the latter was higher than other divisions (82\% for Dhaka, $79 \%$ for Chittagong and $71 \%$ for Khulna).

\subsection{Changes in Average Family Size in Rural, Urban and Municipality}

The changes of average family size are reflected between Muslim and other ethnic groups with rural and urban background in Bangladesh. The data in two census years, 1991 and 2011 reveal that rate of average family size changes between Muslim and other ethnic groups with rural and urban (also municipality) in the 1974 and 1981 census year was decreasing, while the rate of average family size changes of the communities in the next two census years, 1991 and 2011 was growing first. That is average family size was gradually reducing in both the communities, including municipality of Bangladesh. It was interesting to note that average rural family size of the Muslim compared to other ethnic groups size was reducing to some extent, but urban and municipal family size of the minority ethnic groups, compared to the Muslim, was increasing. 


\section{CONCLUSION AND IMPLICATIONS}

Bangladesh is an over-populated but poor country in the world. This over-population with lower quality of man-power not only affects economic development but also affects social welfare functions as a whole (Gain ed., 1998). In order to reduce and control over-population the government of Bangladesh adopted two-child policy for per couple or family. But data derived from over the censuses showed that average family size across the region and rural-urban religious/ethnic groups was two to three-folds higher than the family size policy expected. In addition, the data also showed that rates of changes in average family size across the region and religious/ethnic groups were slower than that targeted in the family policy (BBS, 2013). These variations and slower changes in average family size across the regions and rural-urban ethnic communities may be put into future social welfare policy that may accelerate changes in over-family size. Based on analysis and its arguments the following section describes future social welfare policy-practice. In demographic transition Bangladesh belongs to second position where both fertility and child mortality, including maternal mortality were higher among the poor families compared to middle class or upper class (Akber \& Halim, 1978; BBS, 2001; Haq \& Haq, 1998). Based on the findings and its analysis the government of Bangladesh should include new social policy and programs, including universal old-age security, women empowerment, changes in traditional values and diet system (Uddin, 2015).

To implement the social policy-programs social workers play an important part to reduce and change in over-family size, especially in the Muslim community. Regarding this social workers broadly view that reducing higher family size more or less depends on the changes in eligible ethnic couples' sociocultural, demographic, technological, and political status (especially women status) in the family as well as in the society (Uddin, 2015). Social workers further argue that every ethnic couple in patriarchal, traditional society prefers sons for their socio-cultural continuation, old-age security, ultimate human adaptation and well-being that accelerate high fertility. This high fertility trend is more likely to perpetuate higher family size in this country. Achievement of small family size norms, therefore, fully depend on changes in the level of living conditions and demographic behavior of the eligible couple concerned (Mitra et al. 1994; Mitra \& Kamal, 1985). To achieve this fundamental goal social work knowledge, values and its related social practices are important to reduce and change in over-family size in Bangladesh

\section{ACKNOWLEDGEMENT}

It is my humble attempt to express my deepest sense of gratitude, sincere appreciation and hearty indebtedness to all those experts and researchers whose data, experiences, books and articles helped me in developing the ideas expressed and presented in this research.

\section{REFERENCES}

[1] Akber, M. A. \& Halim, A. M. (1978). Socio-economic factors affecting family size norms and fertility pattern in Bangladesh, Rajshahi: Popullar Press, 1st edition.

[2] Barkat, A., and Howlader, S. R. (1996). Population and development; national plan of action (p. 74). Dhaka: Bangladesh Progressive Enterprise Limited.

[3] Bangladesh Bureau of Statistics (1974). Bangladesh population census report. Dhaka: Statistics Division, Ministry of Planning, Government of the People's Republic of Bangladesh.

[4] Bangladesh Bureau of Statistics (1991). Bangladesh population census report. Dhaka: Statistics Division, Ministry of Planning, Government of the People's Republic of Bangladesh, Vol. 1.

[5] Bangladesh Bureau of Statistics (2001). Preliminary Report: Population Census 2001(p. 18). Dhaka: Statistics Division, Ministry of Planning, Government of the People's Republic of Bangladesh.

[6] Bangladesh Bureau of Statistics (2013). Preliminary Report: Population Census 2011(p. 18). Dhaka: Statistics Division, Ministry of Planning, Government of the People's Republic of Bangladesh.

[7] Bangladesh Bureau of Statistics (1982). Statistical yearbook of Bangladesh (pp. 37-93). Dhaka: Statistics Division, Ministry of Planning, Government of the People's Republic of Bangladesh, 11th edition.

[8] Bangladesh Bureau of Statistics (1991). Statistical yearbook of Bangladesh (pp. 24-25). Dhaka: Statistics Division, Ministry of Planning, Government of the People's Republic of Bangladesh.

[9] Bangladesh Bureau of Statistics (1997). Statistical yearbook of Bangladesh (pp. 24-25). Dhaka: Statistics Division, Ministry of Planning, Government of the People's Republic of Bangladesh.

[10] Bangladesh Bureau of Statistics (2001). Statistical yearbook of Bangladesh. Dhaka: Statistics Division, Ministry of Planning, Government of the People's Republic of Bangladesh.

International Journal of Research in Sociology and Anthropology (IJRSA)

Page $\mid 32$ 
[11] Bangladesh Bureau of Statistics (2002). Statistical yearbook of Bangladesh 2000 (pp. 42-43). Dhaka: Statistics Division, Ministry of Planning, Government of the People's Republic of Bangladesh (June), 21 edition.

[12] Gill, K. K. (1995). Population growth, family size and economic development. New Delhi: deep and Deep Publications.

[13] Gain, P. (ed.) (1998). Bangladesh environment : Facing the 21st Century. Dhaka: Society for Environment and Human Development (SEHD).

[14] Haq, Mahbub-ul and Haq, K. (1998), Human development in South Asia (p. 87). Dhaka: UPL.

[15] Mitra, S. N., \& Kamal, G. M. (1985). Bangladesh contraceptive prevalence survey- 1983. Dhaka: Mitra and Associates.

[16] Mitra, S. N. et. al. (1994). Bangladesh demographic and health survey 1993-1994. Dhaka: Mitra and Associates.

[17] Uddin, M. E. (2010). Family structure: a cross-cultural comparison between Muslim and Santal communities in rural Bangladesh. Saarbruchen: Lambert Academic Publishing.

[18] Uddin, M. E., \& Ferdous, J. (2009). Gender of birth control methods practice in sexual behavior patterns in Bangladesh: A literatures review. Antrocom: Online Journal of Anthropology, 5(2), 87-91.

[19] Uddin, M. E. (2015). Ethnic disparity in family socio-economic status in Bangladesh: Implication for family welfare policy-practice. Global Social Welfare: Research, Policy, and Practice, 2(2), 29-38.

[20] UNICEF (1996). The state of the World's children (p. 86). Oxford University Press.

[21] UNICEF (1997). The state of the World's children (p.86). Oxford University Press.

[22] UNICEF (2001). The state of the World's children (p.90). Oxford University Press.

[23] United Nations (1963), The Determinants and Consequences of Population Trends. New York, pp. 71-96.

[24] United Nations (1993). Population and development planning (p. 85, 87). New York.

[25] United Nations, (2000). World population monitoring 1998: health and mortality: selected aspects. New York

[26] United Nations (2001). National Population Policies (p.65). New York.

Citation: A. H. M. Mahbubur Rahman. "Ethnic Community Variation and Change in Over-Family Size in Bangladesh: 1971-2011" International Journal of Research in Sociology and Anthropology (IJRSA), vol 4, no. 3, 2018, pp. 29-33. doi:http://dx.doi.org/10.20431/2454-8677.0403003.

Copyright: (C) 2018 Authors. This is an open-access article distributed under the terms of the Creative Commons Attribution License, which permits unrestricted use, distribution, and reproduction in any medium, provided the original author and source are credited. 